\title{
The Effect of VBA for Microsoft Excel as Teaching Material to Improve Prospective Elementary School Teachers' Mathematical Conceptual Understanding
}

\author{
Siti Ruqoyyah ${ }^{\otimes_{1}}$, Sukma Murni², Tommy Tanu Wijaya ${ }^{3}$ \\ 1,2 Primary School Teacher Education Study Program, IKIP Siliwangi, Cimahi City, Indonesia \\ 3 Department Mathematics and Statistics, Guangxi Normal University, Guangxi, China \\ $\triangle$ siti-ruqoyyah@ikipsiliwangi.ac.id
}

\begin{abstract}
This research is motivated by the low ability to understand mathematical concepts possessed by prospective elementary school teacher students. This study aims to see the achievement and improvement of students' mathematical understanding abilities that use Microsoft Excel-based VBA teaching materials with those using conventional learning. This study uses a quasi-experimental method with a non-equivalent pre-test and post-test control group design. This study's population were all second-semester elementary school teacher candidates in one private university in West Java, Indonesia. The sample in this study was 70 prospective 2 nd-grade elementary school teacher candidates. The instrument used in this study was a test of understanding mathematical concepts. The results showed: 1) learning using VBA Microsoft Excel as a teaching material was able to improve students' ability to understand mathematical concepts; 2) learning using Microsoft Excel VBA as teaching material is better than conventional learning; and 3) students can be enthusiastic, active and motivated in learning mathematics with VBA Microsoft Excel.
\end{abstract}

Keywords: microsoft excel VBA, understanding of the mathematical concept, teaching materials, elementary school students'

How to Cite: Ruqoyyah, S., Murni, S., \& Wijaya, T. (2020). The Effect of VBA for Microsoft Excel as Teaching Material to Improve Prospective Elementary School Teachers' Mathematical Conceptual Understanding. Mimbar Sekolah Dasar, 7(2), 251-268. doi:https://doi.org/10.17509/mimbar-sd.v7i2.26494.

INTRODUCTION Indonesia experiences an emergency understanding of mathematics. This problem is consistent with the statement: 1) Indonesia experienced a 'mathematical emergency' due to a decline from year to year, and there was no progress in understanding mathematics as school levels increased, 2) During the 14 years from 2000 to 2014, the development of mathematical understanding in Indonesian children only increased slightly, is 11 percent, 3) Based on Indonesia Family Life Survey (IFLS) data in 2000, 2007 and 2014 representing 83 percent of the population of Indonesian children, Indonesian children have an average low competency score in mathematical understanding (Cahyani, 2018). Based on the 2016 Indonesian Student Competency Assessment (AKSI / INAP) from the Ministry of Education and Culture's Ministry of Education and Culture Assessment Center, national data shows 77.13 percent of elementary students have meager mathematical abilities. Only 20.58 percent are moderate, and only 2.29 have a high ability (Harsusilo, 2019). 
Siti Ruqoyyah et al., The Effect of VBA for Microsoft Excel...

A study conducted by the Trends in International Mathematics and Science Study (TIMSS) in 2015 showed that Indonesian student achievement was ranked 46 of the 51 countries studied. It is still far from other countries (Çalışkan et al., 2018). Likewise, Indonesia's PISA position (Program for International Student Assessment) assessment or an international student assessment program in 2018 that assesses mathematics, science, and reading skills is also not good. Of the 80 countries tested, Indonesia's position is ranked 72. In the mathematics assessment alone, Indonesia is ranked 7th from the bottom with an average score of 379 . Down from rank 63 in 2015 (OECD, 2018). It can be seen in figure 1 (Dewabrata, 2019).

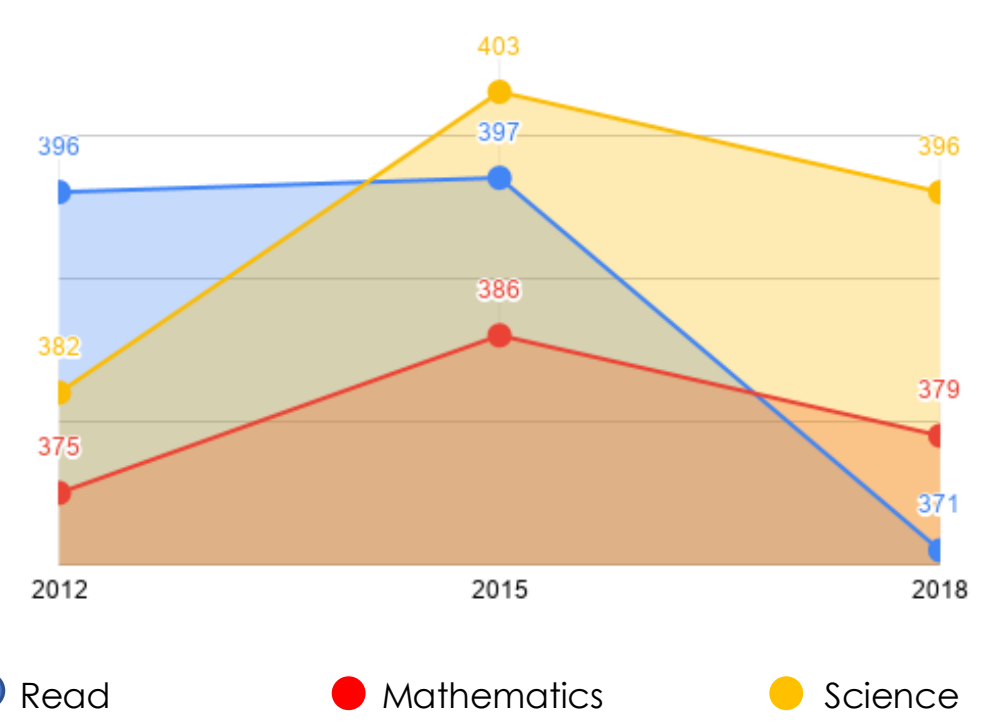

Figure 1. PISA Indonesia Lesson cores in 2012, 2015, 2018

Many factors cause mathematics achievement decline. Based on the researcher's experience, the factors that cause the decline in mathematics learning achievement include elementary to high school students only learning to count or simple counting compared to understanding deep mathematical concepts. Students only calculate and process formulas without knowing the actual mathematical concepts.

From the problems and causal factors that arise from the statements above, understanding mathematical concepts is essential. Students' understanding of mathematical concepts in elementary school is crucial student in understanding mathematics basics. Understanding the concept consists of two words, namely understanding and concepts that each have meaning. Understanding is a translation of the term understanding, which is interpreted as the absorption of the meaning of studied material. It can also be interpreted as the ability to explain a situation or problem that is happening, capture the meaning and meaning of the material being studied (Pape \& Tchoshanov, 2001). 


\section{LITERATURE REVIEW}

\section{Mathematical Conceptual Understanding}

Concepts are abstract intellectual representations that allow a person to group or classify objects or events into examples or not examples of the idea (Akkaya et al., 2011; Kustos \& Zelkowski, 2013). According to Kilpatrick et al. (2001), concept understanding is the ability to understand concepts, operations, and mathematics relations. Cultivating the idea of learning stages emphasizes the delivery of new concepts to students (Agyei, 2019; Reis, 2010). Students will understand the latest knowledge of students' understanding when the incoming (recent) experience is connected with existing knowledge in the student's cognitive structure (Minarni et al., 2016). Understanding mathematics is like building a house. The foundation (concept) must be strong so that the guard stands firmly. The concept is likened to the foundation, basis, or main requirement in learning mathematics. To make it easier to learn higher mathematics material, the concepts that are mastered must be vital.

Mathematical concepts that students get in elementary school will be a provision for students to accept mathematical concepts at the next level and are expected to be applied in everyday life (Babinčáková et al., 2020; Chang et al., 2011; Duval, 2017). Following opinions from Fennema \& Romberg (1999), mathematics teaching aims to emphasize one's understanding of the benefits of mathematics in daily life or the world of work. When students learn mathematics, they must reach a deep and meaningful understanding of mathematics. For elementary school students' knowledge of mathematics to be better, there is a need for the teacher's role in making it happen. The teacher has a central role in realizing the desired learning goals. Understanding mathematical concepts will be transferred to students if the teacher can understand mathematical concepts. It will happen when the teacher becomes a student.

Preliminary studies conducted by researchers in measuring the ability to understand mathematical concepts in prospective elementary school teachers in the early semester showed students were still having difficulty solving simple mathematical problems related to understanding mathematical concepts. For example, the question is given: "Explain the decrease in the volume formula of the jar!" More than $50 \%$ of students have difficulty answering these questions. The majority of students' answers only write down the tube volume formula without explaining the volume build formula's origin. It shows the ability to understand the concepts possessed by prospective elementary school teacher students is still lacking. They only memorized the tube volume formula without knowing the decrease. Similar research conducted (Tsany et al., 2020) shows students' understanding of school mathematical concepts can be said to be lacking. Most students only memorized the formula without knowing the path of completion or the initial formula on which the questions 
Siti Ruqoyyah et al., The Effect of VBA for Microsoft Excel...

were given. It can be seen when students find it difficult if given questions of different types. Students fail to solve math problems well because they experience difficulties understanding concepts and a lack of adequate reasoning in doing the given questions or tests.

According to Özyurt et al. (2014), every abstract concept in mathematics given to students must be strengthened to settle and lasts long in students' memory to cling to their thought patterns and action patterns. Therefore, learning is needed not merely memorizing but understanding, so what is being learned by students will be meaningful and remembered (Bernard \& Chotimah, 2018). Efforts to overcome these problems require research that focuses on understanding students' mathematical concepts whose learning is innovative. Partnership for 21 st Century Learning (2015) develops learning frameworks in the 21 st Century that require students to have skills, knowledge, and abilities in technology, media and information, learning and innovation skills, and life and career skills (Suan et al., 2020; Wijaya, Jianlan, \& Aditya, 2020). Students in the 21st Century must have critical thinking skills, creative thinking, communication skills, and collaboration skills. Students must also have media and technology skills, including information literacy, media literacy, and ICT literacy. Education systems must be equipped with the prerequisite hardware and software for ICT resources, and curricula must be designed to promote a learner-centered and collaborative environment in which students will relate and respond (Boholano, 2017).

\section{Visual Basic Application}

Visual Basic for Excel is a programming language from Microsoft Excel that can utilize a mathematical function that sets figural objects, called "shape," to be more interactive. Students can bring up various ideas that come to their mind using an open-ended approach. The approach is useful when troubleshooting students about the images already provided in the "Forms" menu in Microsoft Excel. The Microsoft Excel VBA teaching material used in this study measures the understanding of mathematical concepts in the material in space (Rohaeti et al., 2019). The reasons for using Microsoft Excel VBA as teaching material are as follows: 1) Microsoft Excel VBA is used to help students understand the concept of building space such as building a cube space from characteristics to cube volume; 2) Helping students improve their skills in using ICT, students also learn how to make Microsoft Excel VBA that has been designed by the lecturer; 3) VBA Microsft Excel-based teaching materials can be easily understood by students, students and teachers and low-cost (Wijaya, Zulfah, Hidayat, et al., 2020).

The use of Microsoft Excel VBA as teaching material to improve the ability to understand elementary school students' mathematical concepts is based on several previous studies (Wijaya, Ying, Cunhua, et al., 2020). Research conducted by Baya'a \& Daher (2013), Ketelhut 
(2019), and Lee \& Kim (2017) show that there is an influence of ICT in improving students' understanding of mathematical concepts. The use of ICT media is also very useful in enhancing the understanding of mathematical concepts. Herawaty \& Widada (2017) state that understanding students' concept by the Contextual Learning model is better than the Conventional Learning Model. Subsequent research conducted by Murni et al. (2020) states that students' mathematical creative thinking abilities are better than before; students enjoy using Microsoft Excel VBA and being active and creative. Rahayu \& Arga (2019) states that students who get learning with Monopoly VBA based learning materials Microsoft Excel are better than conventional learning.

Other research conducted by Bernard et al. (2019) stated that the learning process with a contextual approach assisted by VBA Learning Media (Visual Basic Application for Excel) positively influenced students' mathematical understanding and self-confidence. Similar research was conducted by Bernard et al. (2018), who stated that students experienced increased comprehension skills when learning mathematics using VBA-based math games for Microsoft Excel. Students' confidence had a more positive response. And VBA-based mathematics Games for Microsoft Excel were an alternative to improve students' understanding skills in junior high school.

\section{Focus of Research}

From previous studies, no research discusses the ability to understand mathematical concepts that utilize technology such as VBA Microsoft Excel, especially for elementary school students. It has led to researchers' interest in researching VBA Microsoft Excel teaching materials better to understand mathematical concepts for prospective elementary school teacher students. Therefore, the formulation of the problem in this study: is the achievement and improvement of the ability to understand mathematical concepts of prospective elementary school teacher students whose learning uses Microsoft Excel VBA-based teaching materials better than conventional learning? The purpose of this study was to examine the achievement and improvement as well as the effectiveness of learning using Microsoft Excel VBA teaching materials in improving the mathematical understanding of prospective elementary school teacher students.

\section{METHOD}

\section{Research Design}

The method in this study is quasi-experimental. In quasi-experimental subjects are not randomly grouped, but researchers accept the state of makeshift subjects. Ruseffendi (2010) states that for Quasi-Experimental designs with non-equivalent designs, pre-test and post-test control group design. Both groups both received pre-test and post-test, but only the 
Siti Ruqoyyah et al., The Effect of VBA for Microsoft Excel...

experimental group was given treatment. Learning in the experimental class uses VBA with Microsoft Excel while learning in the control class uses conventional learning. The design of this study is as follows (Hidayat et al., 2018):

Tabel 1. Research Design Non-Randomized Pretest-Posttest Control Group Design

\begin{tabular}{cccc}
\hline Class & Pre-test & Treatment & Post-test \\
\hline Experiment & $O$ & $X_{1}$ & 0 \\
Control & $O$ & $X_{2}$ & 0 \\
\hline
\end{tabular}

Information:

O: Pretest-posttest ability to understand mathematical concepts

$X_{1}$ : Learning uses Microsoft Excel VBA-based teaching materials

$\mathrm{X}_{2}$ : Conventional learning

\section{Research Procedure}

This research was conducted in three stages: the planning stage, the implementation stage, and the completion stage. The planning stage consists of 1) analyzing previous studies on understanding mathematical concepts, 2) analyzing student teaching materials, 3) compiling Microsoft Excel VBA-based media, 4) preparing for the implementation of learning in the experimental class using Microsoft Excel VBA, 5) preparing preparations implementation of learning in the control class with conventional learning, 6) compiling instruments and validating instruments. Instrument validation is done by examining student instruments in measuring the ability to understand mathematical concepts, and then experts validate the device. After that, the instrument was tried out in the class that had received the material to be studied. The second stage is implementation, as for the steps: 1) implementing the pre-test in the experimental and control classes, 2) implementing learning with Microsoft Excel VBAbased teaching materials for the experimental class and conventional learning for the control class, 3) implementing post-tests for the experimental and control classes. The last stage is completion, while the steps are: 1) evaluating learning activities in the experimental and control classes, 2) processing and analyzing data, 3) and concluding from the research results.

\section{Participants}

This study was conducted in one of the private education colleges in Cimahi, West Java, Indonesia. The population in this study were all semester two elementary school teacher candidates. The total number of participants is 70 students, with each class totaling 35 participants. Participants in the experimental class totaled 35 participants, consisting of five men and 30 women. The control class participants consisted of 35 students, consisting of 
seven men and 28 women. The age range for all participants aged 19-21 years. Researchers chose two groups of samples in the second semester. Groups one and two were randomly selected to determine the control class and the experimental class. Both groups were given a pre-test and post-test with the same questions. The reason for choosing second-semester students is that second-semester students can adapt well to utilizing IT-based applications or learning media. The instrument used in this study was a test of the ability to understand mathematical concepts. The instrument was validated by experts and tested in the field, then used in pre-test and post-test, processed, and analyzed using SPSS 25.

\section{RESULTS}

The descriptive summary of the overall mathematical concept understanding score can be seen in table 2.

Tabel 2. Recapitulation Score Understanding of Mathematical Concepts

\begin{tabular}{|c|c|c|c|c|c|c|c|}
\hline \multirow{5}{*}{$\begin{array}{l}\text { Understanding } \\
\text { of } \\
\text { Mathematical }\end{array}$} & \multicolumn{4}{|c|}{$\begin{array}{l}\text { Learning using Microsoft } \\
\text { Excel VBA Based Learning } \\
\text { Materials } \\
(\mathrm{N}=35)\end{array}$} & \multicolumn{3}{|c|}{$\begin{array}{l}\text { Conventional Learning } \\
\qquad(\mathrm{N}=35)\end{array}$} \\
\hline & & Pre-test & Posttest & N-Gain & Pre-test & Posttest & $\mathrm{N}$-Gain \\
\hline & $\bar{x}$ & 52.08 & 70.15 & 0.82 & 53.12 & 65.52 & 0.52 \\
\hline & $\%$ & 52.08 & 70.15 & & 53.12 & 65.52 & \\
\hline & Sd & 9.58 & 12.14 & 0.89 & 9.49 & 10.82 & 0.57 \\
\hline
\end{tabular}

Ideal maximum score: 100

Table 2 shows that the average score of the pre-test ability to understand the experimental class's mathematical concepts was 52.08, and the control class showed 53.12. It can be seen that the average score of the pre-test's ability to understand mathematical concepts is almost the same. While the average post-test scores of mathematical resilience in the class learning using VBA-based Microsoft Excel teaching materials are much better than classes that use conventional learning. Likewise, with the N-Gain score on understanding mathematical concepts, the experimental class showed a significant improvement compared to the control class.

Furthermore, the pre-test and post-test scores and N-Gain's ability to understand the mathematical concepts of the two classes are tested for normality to see whether the data is normally distributed or not. The normality test used is the Kolmogorov-Smirnov test. If the data are normally distributed, then proceed with the homogeneity test, and if the data are not normally distributed, then proceed with the Mann-Whitney test. According to Riduwan (Ruqoyyah et al., 2020), the final test is the average difference test to see the differences between the two classes. The recapitulation of the pre-test score for the understanding of mathematical concepts can be seen in Table 3. 
Siti Ruqoyyah et al., The Effect of VBA for Microsoft Excel...

Tabel 3. Recapitulation of Pretest Score Ability to Understand Mathematical Concepts

\begin{tabular}{|c|c|c|c|c|c|}
\hline \multirow{10}{*}{$\begin{array}{l}\text { Pre-test } \\
\text { scores the } \\
\text { ability to } \\
\text { understand } \\
\text { mathematical } \\
\text { concepts }\end{array}$} & \multirow{2}{*}{ Class } & \multicolumn{3}{|c|}{ Statistical Test Results } & \multirow[t]{2}{*}{ Information } \\
\hline & & Normality & Homogeneity & T-test & \\
\hline & Experiment & 0.192 & \multirow{8}{*}{$\begin{array}{c}0.832 \\
\text { Homogenous }\end{array}$} & \multirow{8}{*}{$\begin{array}{c}0.649 \\
\mathrm{H}_{0} \\
\text { accepted }\end{array}$} & There is no \\
\hline & & o.1 & & & $\begin{array}{l}\text { difference in the } \\
\text { scores of students' }\end{array}$ \\
\hline & & 0.200 & & & initial mathematical \\
\hline & Control & Normal & & & comprehension \\
\hline & & & & & ability in learning \\
\hline & & & & & using VBA based \\
\hline & & & & & $\begin{array}{l}\text { Microsoff Excel } \\
\text { teaching materials }\end{array}$ \\
\hline & & & & & $\begin{array}{c}\text { and those using } \\
\text { conventional } \\
\text { learning }\end{array}$ \\
\hline
\end{tabular}

Based on Table 3, it appears that the pre-test scores of the two classes are normally distributed. It can be seen in the experimental class score is 0.192 , and the control class is 0.200 , where the value meets the criteria Sig. $>0.05$. Because both classes are normally distributed, followed by a homogeneity test. From the table above, the homogeneity test value on the pre-test score of the ability to understand mathematical concepts was 0.0832 . It is means Sig. $>0.05$, it can be concluded that the variance of both classes is homogeneous. The final test was the average difference test. The pre-test score of the mathematical understanding ability on the average difference test was Sig. (2-tailed) with Sig. 0.649>0.05. Following the testing criteria, $\mathrm{H}_{0}$ is accepted, meaning that there was no difference in students' initial mathematical concept comprehension ability in learning using Microsoft Excel VBA-based teaching materials with those using conventional learning.

Furthermore, testing was done as before for post-test scores in both classes. The summary post-test score of the ability to understand mathematical concepts can be seen in Table 4 .

Tabel 4. Recapitulation of Posttest Score Ability to Understand Mathematical Concepts

\begin{tabular}{|c|c|c|c|c|}
\hline \multirow{5}{*}{$\begin{array}{l}\text { Posttest score } \\
\text { ability to } \\
\text { understand } \\
\text { mathematical } \\
\text { concepts }\end{array}$} & \multicolumn{3}{|c|}{ Statistical Test Results } & \multirow[b]{2}{*}{ Information } \\
\hline & Class & Normality & $\begin{array}{c}\text { Non- } \\
\text { Parametric } \\
\text { Mann } \\
\text { Whitney }\end{array}$ & \\
\hline & \multirow[t]{2}{*}{ Experiment } & 0.041 & & \multirow{3}{*}{$\begin{array}{l}\text { Achievement scores of students' } \\
\text { mathematical concept } \\
\text { comprehension ability to learn } \\
\text { using Microsoft Excel VBA-based } \\
\text { teaching materials are better } \\
\text { than conventional learning }\end{array}$} \\
\hline & & $\begin{array}{c}\text { Not } \\
\text { Normal } \\
0.175\end{array}$ & 0.050 & \\
\hline & Control & Normal & $\mathrm{H}_{0}$ rejected & \\
\hline
\end{tabular}

Based on Table 4, it can be seen that the post-test score of one class is not normally distributed. It can be seen in the post-test score in the experimental class is 0.041 , where the 
value does not meet the criteria Sig. > 0.05, which means the sample comes from populations that were not normally distributed. In comparison, the control class Sig value is 0.175 , where the value meets the Sig criteria. $>0.05$, which means the sample comes from populations that are normally distributed. Based on these tests, because the experimental class comes from populations that were not normally distributed, this test can be concluded that the two classes are not normally distributed. As a result, the variance homogeneity test was not carried out, but a two-tailed test was used using the Mann-Whitney test.

Based on the data in table 4, Sig. (2-tailed) was 0.050 in the Mann Whitney test, so Sig. (1tailed) to $0.050 / 2=0.025$; this value meets the Sig criteria. (1-tailed) $\leq 0.05$. Sig. The value must be divided in half because by using IBM SPSS Statistics 25 software where the Sigconducted to see the two-party test. While that is used in this test to side with one party as the research hypothesis. According to Zhang et al. (2020), the significant display of SPSS is for twotailed (2-tailed) tests because we conduct a one-tailed (1-tailed) hypothesis test, then the value of Sig. (2-tailed) must be divided in half. Test criteria, namely:

If Sig. $(1$-tailed $)=1 / 2 \times$ Sig. $(2$-tailed $)>0.05$ then $\mathrm{H}_{0}$ is accepted

If Sig. $(1$-tailed $)=1 / 2 \times$ Sig. $(2$-tailed $) \leq 0.05$ then $\mathrm{H}_{0}$ is rejected

Because of the value of Sig. (1-tailed) $\leq 0.05$ then $\mathrm{H}_{0}$ is rejected, so it can be concluded that the achievement score of students' mathematical concept comprehension ability learning using Microsoft Excel VBA-based teaching material is better than conventional learning.

After obtaining pre-test scores and post-test scores to understand mathematical concepts, the normalized gain score data was processed. Normalized gain data was processed to see an increase in students' understanding of mathematical concepts in each class group. The recapitulation table for the $\mathrm{N}$-Gain score and the ability to understand mathematical concepts can be seen in Table 5.

Tabel 5. Recapitulation of N-Gain Score Ability to Understand Mathematical Concepts

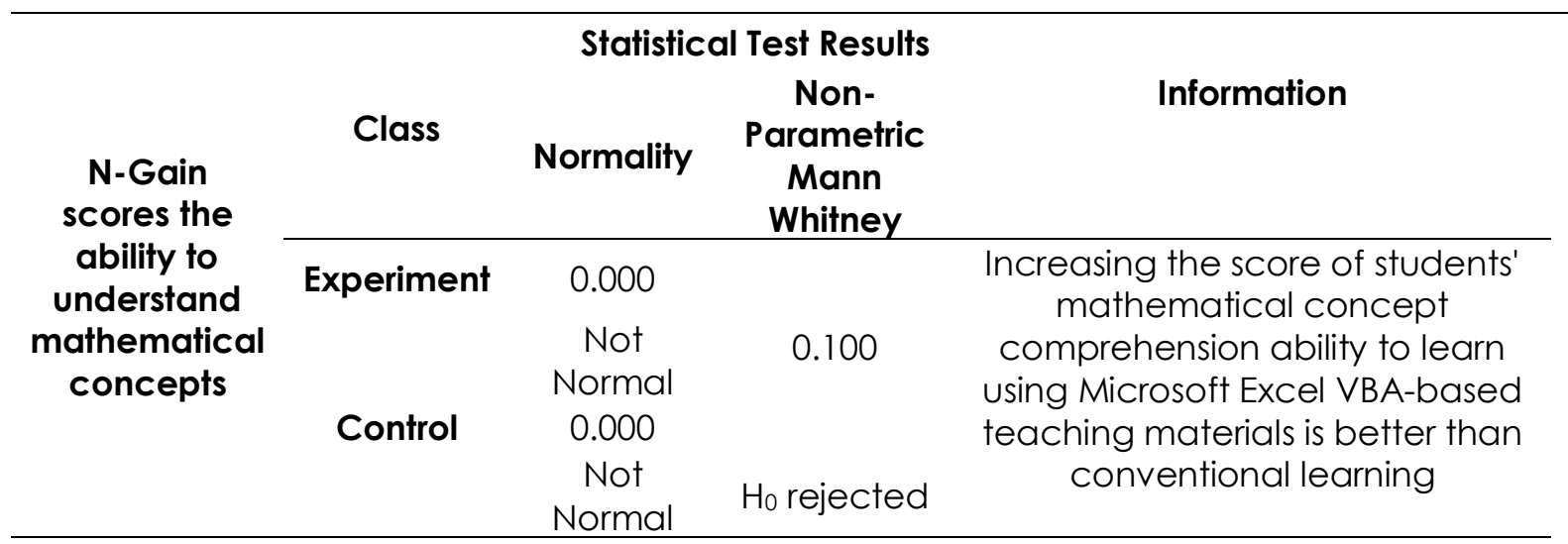


Siti Ruqoyyah et al., The Effect of VBA for Microsoft Excel...

Based on Table 5, it can be seen that the N-Gain score on the ability to understand mathematical concepts of the two classes was not normally distributed. It can be seen in the $\mathrm{N}$-Gain score in both classes is 0.000 , where the value does not meet the Sig criteria. $>0.05$, which means the sample comes from populations that are not normally distributed. Based on these tests, because both classes come from populations that are not normally distributed. As a result, the variance homogeneity test was not carried out, but the Mann-Whitney test is performed.

Based on the data in the table above, Sig. (2-tailed) was 0.100 in the Mann Whitney test so that Sig. (1-tailed) to $0.100 / 2=0.005$, this value meets the Sig criteria. (1-tailed) $\leq 0.05$. It can be concluded that increasing the students' mathematical concept comprehension ability to learn using VBA based Microsoft Excel teaching material is better than conventional learning.

\section{DISCUSSION}

This research was conducted in eight meetings. At the first meeting, a pre-test was carried out in the experimental and control class to see students' initial ability to understand mathematical concepts. The second to the seventh meeting was giving treatment to both classes. The experimental class was given learning treatment with Microsoft Excel VBA-based teaching materials, while the control class received conventional learning. The material discussed at each meeting discusses the material of building space. Constructs discussed spaces such as cubes, blocks, triangular prisms, cubes, pyramids, etc. In the last meeting, each class was given a post-test to see the scope and increase in understanding mathematical concepts in both classes.

\section{Learning in the Experimental Class}

The experimental class was carried out in class A4 of the 2019 elementary school teacher education program. Learning was carried out in groups. Each group was divided into 4-6 students. At the first meeting, students were given a pre-test of their ability to understand mathematical concepts. In the second meeting, students were asked to find and study the building material in groups. Then students were introduced to the VBA Microsoft Excel application, the tools in VBA Microsoft Excel, and how to use them. Students at this meeting were asked to bring laptops to practice and get to know this application immediately. The problem faced by students is that many students are not familiar with this Microsoft Excel VBA application.

Moreover, many students have just heard of this VBA application. Meanwhile, in the 21 st Century, students are required to have skills such as media and technology skills to be able to answer the challenges of work and life. In this Century, students are ready to be skilled and proficient in using technology and information (Häkkinen et al., 2017). 
Students were guided by lecturers practicing and making simple building applications based on Microsoft Excel VBA in the second and third meetings. Students were directed to learn coding on VBA Microsoft Excel in the application they are making. Figure 2 is an example of VBA Microsoft Excel on building materials.

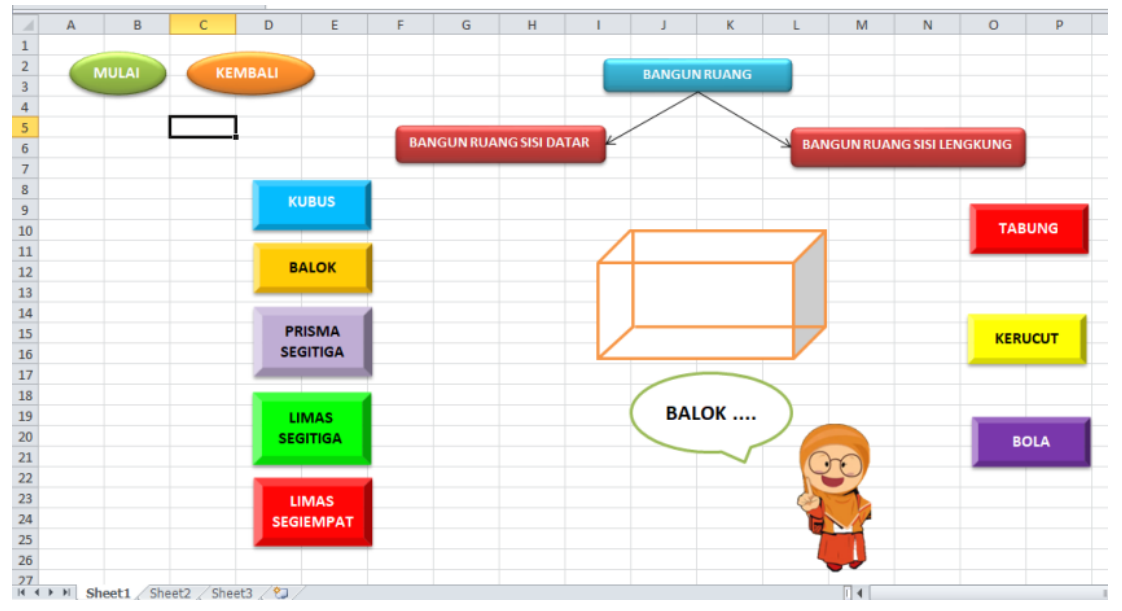

Figure 2. Initial View of VBA Microsoft Excel Building Materials

In the next meeting, students and their groups discussed and tried to make a simple VBA application themselves, following the discussion of building up their respective group rooms. By discussing with a group of students: 1) actively involved in the learning process; 2) students have the skills to ask and discuss a problem; 3) can provide opportunities for students to conduct more intensive investigations about a case or situation; 4) can develop leadership talents and teach discussion skills; 5) can enable teachers to pay more attention to students as individuals and their learning needs; 6) students are more actively involved in their learning, and they are more active in participating in discussions; 7) can provide opportunities for students to develop a sense of respect and personal respect for their friends, respect other people's opinions and help each other in achieving common goals (Esmonde, 2009; Cengiz et al., 2011).

At meetings of five, six, and seven, each group presented the application they had made to the class. With this presentation, it is hoped that students can develop concrete and comprehensive thinking skills, train mental strength, and practice a responsible attitude towards the work that has been done by students. In addition to presenting the application made, each group must also submit a paper. The form is used as a teaching material that explains the building blocks discussed and the steps or ways of making and applying Microsoft VBA that have been made by students. In the last meeting, students were given a post-test to see the achievement and increase in their ability to understand mathematical concepts. 
Siti Ruqoyyah et al., The Effect of VBA for Microsoft Excel...

From the results of interviews with several students, there were many difficulties and difficulties that helped students in making VBA Microsoft Excel-based applications, including 1) many formulas used in making VBA applications, each step of making applications that have different formulas, 2) difficulty determining topics or discussion on the VBA application that will be created, 3) for beginners, creating a VBA Microsoft Excel-based application requires quite a long time. In addition to difficulties, students also explained that with Microsoft Excel VBA, students better understand mathematical concepts in building material, learning becomes fun, active, and motivating students to learn. Students can express their ideas and opinions when working together in making this VBA application with other students. It is following the opinion from Chotimah et al. (2018), that learning mathematics with VBA Microsoft Excel: 1) images can be interactive, students become active and fun to learn mathematics because students understand better understanding without using ICT; 2) it does not cost much to make teaching aids, third, that computer users can access the use of Microsoft Excel software. Chaamwe \& Shumba (2016) also argues that students are pleased to learn using ICT-based media with the Microsoft Excel application because it can make it easier for students to understand mathematical concepts.

Research conducted by Bernard \& Senjayawati (2019) explains that mathematical understanding's ability concluded that VBA-based math games for Microsoft Excel could improve students 'understanding skills and foster students' self-confidence in doing math problems. By using mathematics learning media using VBA for Microsoft Excel, teachers can produce teaching aids that are more practical and efficient as well as helping teachers deliver interactive images related to math material at school. The findings in this study have similarities with the results of the research that has been done. VBA Microsoft Excel can improve students' understanding of learning mathematics material. However, Bernard \& Senjayawati (2019) suggest that it is necessary to pay attention to using VBA Microsoft Excel. First, the importance of good communication between teachers and students because not all of them understand the explanation of VBA for Excel. Second, the teacher must make a VBA strategy for Microsoft Excel media before the teaching and learning process occurs because of the limited time and weight of the material to be delivered.

Furthermore, the research conducted by Romlah et al. (2019) explains that student learning motivation using ICT-based media for VBA excel on number line material in elementary schools is classified as very good. Three indicators are excellent criteria: indicators of trust self in using mathematics (very good), flexible indicators in doing math work (very good), an indicator of willingness to leave other obligations or duties (very good). One indicator falls into the good criteria, namely the persistence indicator in doing mathematics (good). It is explained that VBA Microsoft Excel can increase student motivation in learning mathematics. Even in the research that has been done, students are enthusiastic, active, and motivated in 
making VBA Microsoft Excel applications on building materials. Students understand space building materials and are skilled in making mathematical applications with VBA Microsoft Excel. Ruqoyyah et al. (2020) also argue that in addition to understanding abilities, the achievement of mathematical resilience of students who get learning using Microsoft Excel VBA is better than those using conventional learning. Students learning with Microsoft Excel VBA tend to be able to overcome difficulties if given difficult math problems.

\section{Learning in the Control Class}

Learning in the control class is carried out in class A3 primary school teacher education program. In the first meeting, students were given a pre-test of their ability to understand mathematical concepts. Then at the next meeting, learning in class was carried out in groups. Each group was divided into 4-6 students. Treatment in the control class uses conventional learning. Students are asked to find, study, and make papers on building materials according to the group discussion. Then each group was asked to present to the class. The group presenting in front of the class must also make a PowerPoint to make it easier for other students to understand the material presented.

During the presentation, several findings were found: the lack of students' readiness to deliver material on building space, less attractive presentations by students, and lack of communication skills of students in delivering material or concepts during the presentation. According to Ruqoyyah (2018), communication can be interpreted as delivering messages between two or more people so that the message in question can be understood. As a student, it is essential to have the ability to communicate because they, as prospective school teachers, must have good communication skills before entering the world of work. Before joining the world of work, students must have soft skills, including communicating.

The way to overcome the above findings is to evaluate and reflect on presentations made by students. Evaluating and reflecting on what is lacking and must be improved. From delivering the concept of building space during the presentation, presentation readiness, to the material presented. Besides, providing input and criticism and motivation to the students who appear so that the presentations of other groups will be better at the next meeting. Each student is given a post-test to see the achievement and increase in understanding mathematical concepts of building material by meeting in the control class.

\section{CONCLUSION}

The research concludes 1) learning using Microsoft Excel VBA as a teaching material can improve students' ability to understand mathematical concepts; 2) Learning using Microsoft Excel VBA as teaching material is better according to conventional learning; 3) Students can be enthusiastic, active, and motivated in learning mathematics with VBA Microsoft Excel. 
Siti Ruqoyyah et al., The Effect of VBA for Microsoft Excel...

Recommendations from this study: 1) Microsoft Excel VBA-based teaching materials can be used as learning resources for easily accessible people; 2) Teaching materials must be well prepared to motivate students to learn according to the material being taught; 3) Time management is essential in the use of VBA Microsoft Excel as teaching material.

\section{ACKNOWLEDGMENTS}

Thank you to the Directorate General of Research and Development Strengthening of the Ministry of Research, Technology, and Higher Education for providing research funding through the novice lecturer research program to be carried out smoothly according to the targets and objectives.

\section{REFERENCES}

Agyei, D. D. (2019). From needs analysis to large-scale implementation: Using collaborative design to support ict integration. Collaborative Curriculum Design for Sustainable Innovation and Teacher Learning, 305-328. https://doi.org/10.1007/978-3-030-20062-6_17

Akkaya, A., Tatar, E., \& Kağizmanli, T. B. (2011). Using dynamic software in teaching of the symmetry in analytic geometry: The case of GeoGebra. Procedia - Social and Behavioral Sciences, 15, 2540-2544. https://doi.org/10.1016/j.sbspro.2011.04.141

Babinčáková, M., Ganajová, M., Sotáková, I., \& Bernard, P. (2020). Influence of formative assessment classroom techniques (Facts) on student's outcomes in chemistry at secondary school. Journal of Baltic Science Education, 19(1), 36-49. https://doi.org/10.33225/jbse/20.19.36

Baya'a, N., \& Daher, W. (2013). Mathematics teachers' readiness to integrate ICT in the classroom. International Journal of Emerging Technologies in Learning, 8(1), 46-52. https://doi.org/10.3991/ijet.v8i1.2386

Bernard, M., Akbar, P., Ansori, A., \& Filiestianto, G. (2019). Improve the ability of understanding mathematics and confidence of elementary school students with a contextual approach using VBA learning media for Microsoft Excel. IOP Conf. Series: Journal of Physics: Conf. Series, 1318(1), 012035. https://doi.org/doi:10.1088/1742$6596 / 1318 / 1 / 012035$

Bernard, M., \& Senjayawati, E. (2019). Developing the Students' Ability in Understanding Mathematics and Self-confidence with VBA for Excel. JRAMathEdu (Journal of Research and Advances in Mathematics Education), 4(1), 45-56. https://doi.org/https://doi.org/10.23917/jramathedu.v1i1.6349

Bernard, Martin, \& Chotimah, S. (2018). Improve student mathematical reasoning ability with open-ended approach using VBA for powerpoint. AIP Conference Proceedings, 2014 (September). https://doi.org/10.1063/1.5054417

Bernard, M., Minarti, E. D., \& Hutajulu, M. (2018). Constructing Student's Mathematical 
Understanding Skills and Self Confidence: Math Game with Visual Basic Application for Microsoft Excel in Learning Phytagoras at Junior High School. International Journal of Engineering \& Technology. https://doi.org/10.14419/ijet.v7i3.2.18738

Boholano, H. (2017). Smart Social Networking: 21st Century Teaching and Learning Skills. Research in Pedagogy, 7(1), 21-29.

Cahyani, K. S. (2018). Pemahaman Matematika Anak Indonesia Cuma Naik 11 Persen dalam 14 Tahun (Indonesian Children's Mathematics Understanding Only Raised 11 Percent in 14 Years). Detik Health. https://health.detik.com/berita-detikhealth/d4299399/pemahaman-matematika-anak-indonesia-cuma-naik-11-persen-dalam-14tahun

Çalışkan, N., Kahya, E., \& Durmuş, Y. T. (2018). An Analysis of Mathematics Questions of the TPESE Exam According to Cognitive Levels of TIMMS 2015. 7(5), 67-82. https://doi.org/10.7596/taksad.v7i5.1640

Cengiz, N., Kline, K. \&, \& Grant, T. J. (2011). Extending students' mathematical thinking during whole-group discussions. Journal of Mathematics Teacher Education, 14 (1), 355-374.

Chaamwe, N., \& Shumba, L. (2016). ICT Integrated Learning: Using Spreadsheets as Tools for e-Learning, A Case of Statistics in Microsoft Excel. International Journal of Information and Education Technology, 6(6), 435-440.

Chang, Y. J., Wang, T. Y., Chen, S. F., \& Liao, R. H. (2011). Student Engineers as Agents of Change: Combining Social Inclusion in the Professional Development of Electrical and Computer Engineering Students. Systemic Practice and Action Research, 24(3), 237-245. https://doi.org/10.1007/s1 1213-010-9183-3

Chotimah, S., Bernard, M., \& Wulandari, S. M. (2018). Contextual approach using VBA learning media to improve students' mathematical displacement and disposition ability. Journal of Physics: Conference Series, 948(1). https://doi.org/10.1088/1742-6596/948/1/012025

Dewabrata, M. (2019, December). Hasil PISA 2018 Resmi Diumumkan, Indonesia Alami Penurunan Skor di Setiap Bidang (PISA 2018 Results Officially Announced, Indonesia Has Decreased Score in Every Field). Zenius.Net.

Duval, R. (2017). Understanding the mathematical way of thinking - The registers of semiotic representations. In Understanding the Mathematical Way of Thinking - The Registers of Semiotic Representations. https://doi.org/10.1007/978-3-319-56910-9

Esmonde, I. (2009). Mathematics Learning in Groups: Analyzing Equity in Two Cooperative Activity Structures. Journal of the Learning Sciences, 18(2), 247-284.

Fennema, E., \& Romberg, T. A. (1999). Mathematics Classrooms That Promote Understanding. Lawrence Erlbaum Assoeiates.

Häkkinen, P., Järvelä, S., Mäkitalo-Siegl, K., Ahonen, A., Näykki, P., \& Valtonen, T. (2017). Preparing teacher-students for twenty-first-century learning practices (PREP 21): a framework for enhancing collaborative problem-solving and strategic learning skills. 
Siti Ruqoyyah et al., The Effect of VBA for Microsoft Excel...

Teachers and Teaching, Taylor \& Francis, 23(1), 25-41. https://doi.org/https://doi.org/10.1080/13540602.2016.1203772

Harsusilo, Y. E. (2019). Ironi Matematika: Juara di Olimpiade Miris di Peringkat PISA, Ada Apa? (Mathematical irony: Champion in the Olympics is sad at the PISA Ranking, What's wrong?). Kompas.Com. https://edukasi.kompas.com/read/2019/08/29/10471351/ironimatematika-juara-di-olimpiade-miris-di-peringkat-pisa-ada-apa?page=all

Herawaty, D., \& Widada, W. (2017). The Influence of Contextual Learning Models and the Cognitive Conflict to Understand Mathematical Concepts and Problems Solving Abilities. Proceedings of the 1st Annual International Conference on Mathematics, Science, and Education (ICOMSE 2017), 96-102. https://doi.org/https://doi.org/10.2991/icomse17.2018.17

Hidayat, W., Wahyudin, W., \& Prabawanto, S. (2018). Improving students' creative mathematical reasoning ability students through adversity quotient and argument driven inquiry learning. Journal of Physics: Conference Series, 948(1). https://doi.org/https://doi.org/10.1088/1742-6596/948/1/012005

Ketelhut, D. J. (2019). Contemporary Technologies in Education. Contemporary Technologies in Education, 17-29. https://doi.org/10.1007/978-3-319-89680-9

Kilpatrick, J., Swafford, J., \& Findell, B. (2001). Adding it Up: Helping Childern Learn Mathematics. National Academy Press.

Kustos, P., \& Zelkowski, J. (2013). Grade-continuum trajectories of four known probabilistic misconceptions: What are students' perceptions of self-efficacy in completing probability tasks? Journal of Mathematical Behavior, 32(3), 508-526. https://doi.org/10.1016/j.jmathb.2013.06.003

Lee, C. J., \& Kim, C. M. (2017). A technological pedagogical content knowledge based instructional design model: a third version implementation study in a technology integration course. Educational Technology Research and Development, 65(6), 16271654. https://doi.org/10.1007/s1 1423-017-9544-z

Minarni, A., Napitupulu, E. E., \& Husein, R. (2016). Mathematical understanding and representation ability of public junior high school in North Sumatra. Journal on Mathematics Education, 7(1), 43-56. https://doi.org/10.22342/jme.7.1.2816.43-56

Murni, S., Bernard, M., Ruqoyyah, S., \& Chotimah, S. (2020). PGSD student's mathematical creative thinking skills judging from creativity quotations by making vba-based teaching. Journal of Physics: Conference Series, $1521(3), \quad 032040$. https://doi.org/https://doi.org/10.1088/1742-6596/1521/3/032040

OECD. (2018). PISA 2015 Result in Focus. OECD. https://www.oecd.org/pisa/pisa-2015-resultsin-focus.pdf

Özyurt, Ö., Özyurt, H., Güven, B., \& Baki, A. (2014). The effects of UZWEBMAT on the probability unit achievement of Turkish eleventh grade students and the reasons for such effects. 
Computers and Education, 75, 1-18. https://doi.org/10.1016/j.compedu.2014.02.005

Pape, S. J., \& Tchoshanov, M. A. (2001). The role of representation (s) in developing mathematical understanding. Theory into Practice, Taylor \& Francis, 40(2), 118-127. https://doi.org/https://doi.org/10.1207/s15430421tip4002_6

Partnership for 21 st Century Leaning. (2015). P21 framework definitions: 21 st CENTURY STUDENT OUTCOMES.

https://static.battelleforkids.org/documents/p21/P21_Framework_Definitions_New_Logo_ 2015_9pgs.pdf

Rahayu, G. D. S., \& Arga, H. S. P. (2019). Influence of VBA-based Monopoly Game in Microsoft Excel as Teaching Material on Primary School Students' Cross-Cultural Competence in Social Studies Learning. Mimbar Sekolah Dasar, 6(2), 147-159. https://doi.org/https://doi.org/10.17509/mimbar-sd.v6i2.16935

Reis, Z. A. (2010). Computer supported mathematics with Geogebra. Procedia - Social and Behavioral Sciences, 9, 1449-1455. https://doi.org/10.1016/j.sbspro.2010.12.348

Rohaeti, E. E., Bernard, M., \& Primandhika, R. B. (2019). Developing Interactive Learning Media for School Level Mathematics through Open-Ended Approach Aided by Visual Basic Application for Excel. Journal on Mathematics Education, 10(1), 59-68. https://doi.org/ISSN-2087-8885

Romlah, S., Nugraha, N., \& Setiawan, W. (2019). Analisis Motivasi Belajar Siswa SD Albarokah 448 Bandung dengan Menggunakan Media ICT Berbasis For VBA Excel Pada Materi Garis Bilangan (Analysis of Learning Motivation of Students SD Albarokah 448 Bandung Using ICT-Based Media For VBA Excel on Number Lines). Jurnal Cendekia: Jurnal Pendidikan Matematika., $3(1)$, 220-226. https://doi.org/https://doi.org/10.31004/cendekia.v3i1.98

Ruqoyyah, S. (2018). Meningkatkan Kemampuan Komunikasi Matematik Siswa MA melalui Contextual Teaching and Learning (Improve Mathematical Communication Skills of MA Students through Contextual Teaching and Learning). P2M STKIP Siliwangi, 5(2), 85-99. https://doi.org/10.22460/p2m.v5i2p85-99.1052

Ruqoyyah, S., Murni, S., \& Fasha, L. H. (2020). Microsoft Excel VBA on mathematical resilience of primary school teacher education students. Journal of Physics: Conference Series, 1657(1), 012010. https://doi.org/10.1088/1742-6596/1657/1/012010

Ruseffendi, E. T. (2010). Dasar-dasar Penelitian Pendidikan dan Bidang Non-Eksakta Lainnya (Fundamentals of Educational Research and Other Non-Exact Fields). Bandung: Tarsito.

Suan, L., Ying, Z., \& Wijaya, T. T. (2020). Using hawgent dynamic mathematics software in teaching arithmetic operation. International Journal of Education and Learning, 2(1), 2531. https://doi.org/10.31763/ijele.v2i1.97

Tsany, U. N., Septian, A., \& Komala, E. (2020). The ability of understanding mathematical concept and self-regulated learning using macromedia flash professional 8. Journal of 
Siti Ruqoyyah et al., The Effect of VBA for Microsoft Excel...

Physics: Conference Series, 1657(1), 012074. https://doi.org/doi:10.1088/1742$6596 / 1657 / 1 / 012074$

Wijaya, T. T., Jianlan, T., \& Aditya, P. (2020). Developing an Interactive Mathematical Learning Media Based on the TPACK Framework Using the Hawgent Dynamic Mathematics Software. Emerging Technologies in Computing, 318-328. https://doi.org/10.1007/978-3030-60036-5

Wijaya, T. T., Ying, Z., Cunhua, L., \& Zulfah. (2020). Using vba learning media to improve students ' mathematical understanding ability. Journal On Education, 02 (02), 245-254.

Wijaya, T. T., Zulfah, Z., Hidayat, A., Akbar, P., Arianti, W., \& Asyura, I. (2020). Using VBA for microsoft excel based on 6-questions cognitive theory in teaching fraction. Journal of Physics: Conference Series, 1657(1), 012078. https://doi.org/10.1088/1742$6596 / 1657 / 1 / 012078$

Zhang, L., Zhou, Y., \& Wijaya, T. T. (2020). Hawgent dynamic mathematics software to improve problem-solving ability in teaching triangles. Journal of Physics: Conference Series, 1663(1). https://doi.org/10.1088/1742-6596/1663/1/012069 